\title{
Hapsburg Lip/Jaw and Vadoma Feet Show the Theoretical Possibility of the Emergence of the Different Skull, Lip and Nose Appearances From a Pristine Type Via Inbreeding
}

\author{
Seun Ayoade* \\ Physiology, University of Ibadan, Nigeria \\ Received: 阱June 05, 2018; Published: 眥 June 12, 2018 \\ *Corresponding author: Seun Ayoade, Physiology, University of Ibadan, Nigeria
}

\section{Opinion}

There is no gainsaying that the different ethnicities on earth today exhibit various skull and face appearances. How did this come about? According to creationists all of humanity is descended from just two people; and variations among mankind (according to some creationists) arose via inbreeding. Is this scientifically feasible/ possible? Types of skull and face appearances on earth today include dolicocephalic, mesocephalic, bracycephalic, euryprosopic, mesoprosopic and leptoprosopic. Nose appearances include leptorrhine, mesorrhine and platyrrhine. But could all these skull/ face/nose appearances have emerged and morphed from a single appearance? It is not impossible that in the remote past harmless mutations-triggered by inbreeding could have morphed the original skull/face type into the rich varieties we see today.

Prolonged inbreeding has been known to significantly change skeletal structure and facial appearance as typified by the "ostrich footed" Vadoma tribe of Zimbabwe and the historic peculiar jaw and lipped [mandibular prognathism] members of the inbred European Hapsburg Royal Family [1-4]. The Vadoma tribe of southern Africa number around 16,000. For generations they have not married outside of the tribe, and marriages/sexual liaisons between half brother and sister and between first cousins are rife. Little wonder the Vadoma people have an unusual amount of children born with two huge toes-instead of five regularly sized ones!

This defect, known as ectrodactyly usually occurs very rarely (1 in 10,000 to 90,000) among people who are not inbred. In the Vadoma however the frequency of ectrodactyly is so many times the usual. Ectrodactyly is an autosomal dominant condition resulting from a single mutation on chromosome number 7 . In the light of this Vadoma ostreometrical anomaly it is not impossible to see how inbreeding among pristine humans could have morphed the dolichocephalic skull [cephalic index 74.9 or less] to the mesocephalic [cephalic index 75-79] to the bracycephalic [cephalic index 80 and over] and vice versa. Such craniometrical variations via inbreeding are theoretically feasible.

\section{References}

1. (2013) "The Habsburg Lip" Topics in the History of Genetics and Molecular Biology, Fall 2000. Msu edu.

2. Alvarez G, Ceballos FC, Quinteiro C (2009) "The Role of Inbreeding in the Extinction of a European Royal Dynasty". Plos One 4(4): 5174.

3. Joshua (2015) "Doma, Vadoma in Zimbabwe".

4. Una Strand Viðarsdóttir, Paul O’Higgins, Chris Stringer (2002)”A geometric morphometric study of regional differences in the ontogeny of the modern human facial skeleton". J Anat 201(3): 211-229. 
(c) (P) This work is licensed under Creative To Submit Your Article Click Here:

Submit Article

DOI: 10.32474/LOJNHC.2018.01.000116

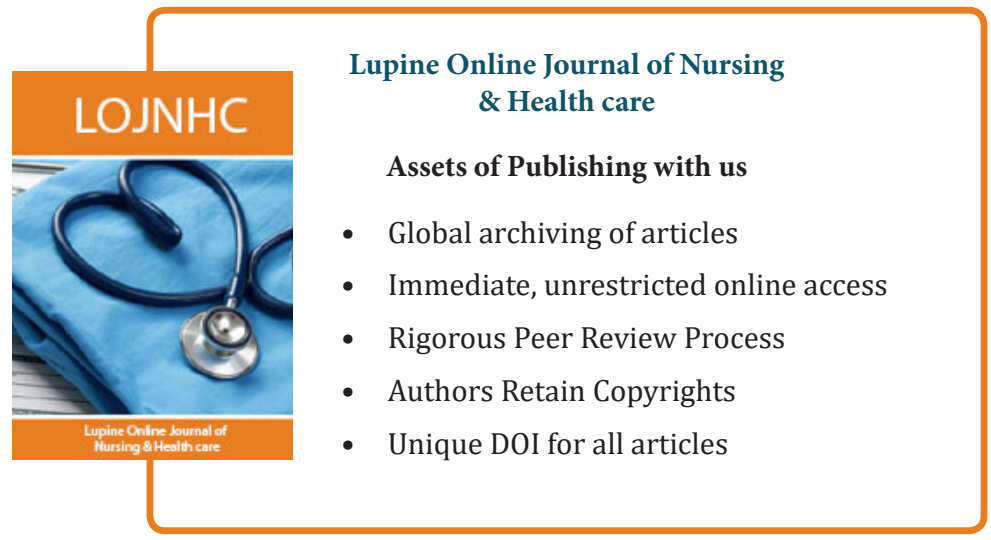

